\title{
Isolation of Enteric Bacteria from Hawked "Kunun-Zaki” in Chikun Local Government Area of Kaduna State
}

\author{
Katuka Yashim Blessed ${ }^{1}$, Anthony John Dadah ${ }^{1}$, Auwalu Uba ${ }^{2}$ \\ ${ }^{1}$ Department of Microbiology, Faculty of Science, Kaduna State University, Kaduna, Nigeria \\ ${ }^{2}$ Department of Microbiology, Faculty of Science, Abubakar Tafawa Balewa University, Bauchi, Nigeria
}

Email address:

blessedyashim@gmail.com (K. Y. Blessed), Tonydadh@yahoo.com (A. J. Dadah), ubaawalu200@yahoo.com (A. Uba)

\section{To cite this article:}

Katuka Yashim Blessed, Anthony John Dadah, Auwalu Uba. Isolation of Enteric Bacteria from Hawked "Kunun-Zaki" in Chikun Local Government Area of Kaduna State. American Journal of Laboratory Medicine. Vol. 2, No. 5, 2017, pp. 96-98. doi: 10.11648/j.ajlm.20170205.13

Received: February 16, 2017; Accepted: March 11, 2017; Published: October 24, 2017

\begin{abstract}
Two hundred samples of freshly formulated Kunun-zaki, a locally fermented non-alcoholic cereal beverages were obtained from local hawkers in five (5) different locations in Chikun Local Government of Kaduna State, Nigeria and screened for enteric bacteria. They were analyzed using the Spread Plate Method. The $\mathrm{pH}$ of the samples ranged between $3.00-7.50$ and total bacterial count ranged between $2.0 \times 10^{4}-9.0 \times 10^{5} \mathrm{cfu} / \mathrm{ml}$. The microorganisms recovered were Esherichia coli, Proteus vulgaris, Proteus mirabilis and Citrobacter freundii. The frequency of the occurrence of the isolated bacteria were: Citrobacter freundii 14 (58\%) Esherichia coli 3 (13\%) Proteus mirabilis 5 (21\%)) and Proteus vulgaris 2 (8\%). The percentage of contamination in each location is as follows: Television $20 \%$, Sabon-Tasha $15 \%$, Mararaban-rido $12.5 \%$, Kujama $7.5 \%$, and Narayi 5\%. There was a significant difference in the rate of contamination $(\mathrm{P}>0.05)$. The presence of these bacteria may be a serious health concern as these organisms are involved in causing various diseases. Therefore, hygienic measures should be taken in processing and handling of the product being sold to general public.
\end{abstract}

Keywords: Kunun-Zaki, Total Bacterial Counts, Beverage, Contamination by Enteric Bacteria

\section{Introduction}

"Kunun-Zaki" is an indigenous fermented non-alcoholic, and non-carbonated beverage [12] which is widely produced and consumed especially in the northern Nigeria [4]. It is consumed by all age groups as a thirst quencher or as refreshment in some communities. It is used for entertainment at homes and during ceremonies and festive periods like Christmas and Sallah and sometimes as a weaning drink for infants [8].

Where religion or health does not permit, kunu is taken in place of other alcoholic drinks like burukutu. It is estimated that over $76 \%$ of northerners drink kunun-zaki on regular basis [14].

The production of kunun-zaki varies amongst people and can generally be produced from either fermented millet (Pennisetum typhoideum), maize (Zea mays) or sorghum (Sorghum bicolor) Millet is however the most common substrate [3].
The traditional process for the production of kunun-zaki involves the steeping of millet grains, wet milling with spices (ginger, cloves and pepper), wet sieving and partial gelatinization of the slurry, followed by the addition of sugar and bottling [7].

The presence of pathogens even in small numbers could render kunun-zaki unsuitable for human consumption [11]. Contamination by pathogens could occur during production, hawking and packaging of the products and poor hygiene practice by the processors [5].

\section{Materials and Methods}

\subsection{Collection of Samples}

Forty (40) samples each of Kunun-zaki were collected from each of the five (5) locations from different hawkers between the hours of 9:00 am to 11:00 am and between the months of May to August, 2016. The samples were collected in sterile plastic bottles using aseptic methods. The bottles 
were well labeled and were immediately taking to the Microbiology laboratory of Kaduna State University (KASU) for processing.

\section{2. pH Determination of the Samples}

The $\mathrm{pH}$ of the samples were determined using a $\mathrm{pH}$ meter (WPA $\mathrm{pH}$ Meter, India) after standardization with $\mathrm{pH} 4$, and 7 buffers (BDH England).

\subsection{Determination of Total Bacteria Count}

Nutrient Agar (NA) (Biotech Lab. Ipswich, UK) was inoculated with $0.1 \mathrm{ml}$ of appropriately diluted kunu-zaki by spread-plating technique and incubated at $37^{\circ} \mathrm{C}$ for 24 hours. Colonies were counted and multiplied by the dilution factor.

\subsection{Isolation of Bacteria from Hawked Kunu-zaki}

Discrete colonies of bacteria were selected and sub cultured from mixed cultures of the plates of Salmonella Shigella Agar (SSA) respective. The plates were incubated at $37^{\circ} \mathrm{C}$ for 24 hours. The bacterial isolates were then identified following standard microbiological procedures based on cultural, morphological and biochemical characteristics as described by [6].

\section{Results}

The mean $\mathrm{pH}, \mathrm{pH}$ range, total bacteria count and the percentage of microbial contamination are shown in Table 1 Result of $\mathrm{pH}$ determination showed that $\mathrm{pH}$ of 7.5 was the highest and $\mathrm{pH} 3.0$ was the lowest, obtained in Sabon-Tasha and Kujama respectively. The organisms recovered is shown in Table 2 The percentage occurrence of enteric bacteria isolated from Kunun-zaki is shown in Table 3

Table 1. $p H$ range, total bacterial count (Cfu/ml) base on locations.

\begin{tabular}{|c|c|c|c|c|c|}
\hline Locations & Mean pH & pH range & Total Bacteria count (cfu/ml) & $\begin{array}{l}\text { Percentage }(\%) \text { of positive } \\
\text { samples }\end{array}$ & $\begin{array}{l}\text { Percentage }(\%) \text { of } \\
\text { negative Samples }\end{array}$ \\
\hline Mararaban-rido & 3.80 & $3.00-6.40$ & $6.4 \times 104-1.2 \times 105$ & 12.5 & 87.5 \\
\hline Sabo-tasha & 3.85 & $3.01-7.50$ & $3.0 \times 104-9.0 \times 105$ & 15.0 & 85.0 \\
\hline Narayi & 4.03 & $3.11-6.50$ & $8.0 \times 104-1.8 \times 105$ & 5.00 & 95.0 \\
\hline Television & 3.88 & $3.06-7.00$ & $3.0 \times 104-2.0 \times 105$ & 20.00 & 80.0 \\
\hline Kujama & 3.94 & $3.00-6.00$ & $2.0 \times 104-9.0 \times 105$ & 7.50 & 92.5 \\
\hline
\end{tabular}

Table 2. Cultural and biochemical characteristic of enteric bacteria isolated from kunun-zaki.

\begin{tabular}{|c|c|c|c|c|c|c|c|c|c|c|c|}
\hline \multirow{2}{*}{ Organisms } & \multirow{2}{*}{ Cultural characteristic } & \multirow{2}{*}{ Urease } & \multirow{2}{*}{ Oxidase } & \multirow{2}{*}{ Citrate } & \multirow{2}{*}{ Indole } & \multirow{2}{*}{ Motility } & \multirow{2}{*}{ Methyl red } & \multicolumn{4}{|l|}{ TSI } \\
\hline & & & & & & & & Slope & Butt & $\mathrm{H}_{2} \mathrm{~S}$ & Gas \\
\hline Citrobacter freundeii & $\begin{array}{l}\text { Translucent with gray shining } \\
\text { surface }\end{array}$ & + & - & + & - & + & + & $\mathrm{Y}$ & $\mathrm{Y}$ & + & + \\
\hline Proteus mirabilis & Transparent with black center & + & - & + & - & + & + & $\mathrm{R}$ & $\mathrm{Y}$ & + & + \\
\hline Proteus vulgaris & Transparent with black center. & + & - & + & - & + & + & $\mathrm{R}$ & $\mathrm{Y}$ & + & + \\
\hline Escherichia coli & Smooth pink and rosy & + & - & - & + & + & + & $\mathrm{Y}$ & $\mathrm{Y}$ & - & + \\
\hline
\end{tabular}

Keys: $\mathrm{Y}=$ Yellow (acid reaction), $\mathrm{R}=\mathrm{Red}($ alkaline $),(+)=$ Positive, $(-)=$ Negative

Table 3. Percentage occurrence of enteric bacteria isolated from kunun-zaki.

\begin{tabular}{lll}
\hline Organisms & Frequency & Percentage (\%) \\
\hline Citrobacter freundii & 14 & 58 \\
Escherichia coli & 3 & 13 \\
Proteus mirabilis & 5 & 21 \\
Proteus vulgaris & 2 & 8 \\
\hline
\end{tabular}

\section{Discussion}

In this work, the highest $\mathrm{pH}$ of kunun-zaki was 7.5 and the lowest $\mathrm{pH}$ was 3.00 , obtained from Sabon-Tasha and Kujama respectively. The $\mathrm{pH}$ range of the "kunun-zaki" in decreasing order are as follows: Sabon-tasha 3.01 to 7.5 , Television 3.06 to 7.0, Narayi 3.11 to 6.5 , Marara-rido 3.0 to 6.4 , and Kujama 3.0 to 6.0 . 3.95 to 4.08 were however obtained by [14]. Our values were higher than the values 4.12 to $5.10,4.70$ to 5.75 and 5.25 to 5.65 obtained by [2], [3], [4]. The acidic nature of the "kunun-zaki" is as a result of fermentation process which led to the production of lactic acid by bacteria. That increased the flavor and lower the $\mathrm{pH}$ of the kunu. The low $\mathrm{pH}$ reduce the activities of pathogens [13], [15]. Statistically there is no significant differences in the $\mathrm{pH}$ values in all locations
$(\mathrm{P} \leq 0.05)$.

The total bacteria count (TBC) in Table 1 showed a decrease in the order of the bacteria count. Sabon-Tasha had the highest TBC of $3 \times 10^{4}$ to $9.0 \times 10^{5} \mathrm{cfu} / \mathrm{mls}$ followed by Kujama with $2.0 \times 10^{4}$ to $9.0 \times 10^{5} \mathrm{cfu} / \mathrm{mls}$, Television with $3.0 \times 10^{4}$ to $2.0 \times 10^{5}$ $\mathrm{cfu} / \mathrm{mls}$, Narayi with $8.0 \times 10^{4}$ to $1.8 \times 10^{5} \mathrm{cfu} / \mathrm{mls}$ and Mararabanrido had the lowest $6.4 .0 \times 10^{4}$ to $1.2 \times 10^{5} \mathrm{cfu} / \mathrm{mls}$. This are all lower compared to the $7.33 \times 10^{6} \mathrm{cfu} / \mathrm{mls}$ to $81.67 \times 10^{6} \mathrm{cfu} / \mathrm{mls}$ obtained by [4]. But however, it fell within the range of findings by [1], [8], [9], and [11] Who reported bacteria count of $5.1 \times 10^{2}$ to $2.0 \times 10^{8} \mathrm{cfu} / \mathrm{mls}, 1.0 \times 10^{2}$ to $8.9 \times 10^{4} \mathrm{cfu} / \mathrm{mls}, 3.5 \times 10^{4}$ to $8.4 \times 10^{4} \mathrm{cfu} / \mathrm{mls}$ and $5.0 \times 10^{4}$ to $1.79 \times 10^{5} \mathrm{cfu} / \mathrm{mls}$, and. The high bacteria count therefore might be as a result of unclean water used in the preparation of the kunu, poor hygienic practice, exposing the kunun-zaki to dust and flies. Improper hand washing after going to the toilet during the preparation of the 
kunu can also lead to contamination [5], [9], [10]. The percentage of contamination in increasing order showed that Television had highest percentage of $20 \%$, Sabon-Tasha $15 \%$, Mararaban-rido $12.5 \%$, Kujama $7.5 \%$ and the lowest was Narayi with $5.0 \%$. These show improvement in hygienic practice among kunun-zaki producers and sellers and less contamination of the product [13]. There was a significant difference in rate of contamination at $95 \%$ confidence interval when the $\mathrm{P}$-value is $5 \%$.

Table 2 shows the organisms recovered in all of the samples. They include the following: C. freundii, E. coli, P. mirabilis and P. vulgaris.

Table 3 showed the percentage occurrence of enteric bacteria out of the two hundred (200) samples examined. The rate of contamination by bacteria was as follow: Citrobacter freundii 14 (58\%), Proteus mirabilis 5 (21\%), Escherichia coli $3(13 \%)$ and Proteus vulgaris $2(8 \%)$. All the organisms isolated from this study are important members of the coliform group. They are part of the normal flora of humans. Their habitat include soil, water, sewage, food, animal and human intestine. Some strains can cause gastroenteritis, diarrhoea and urinary tract infection. There presences are indicator of faecal contamination of the kunun-zaki. These organisms are opportunistic pathogens that can cause disease in immunosuppressed people, they cause diseases such as respiratory and urinary tract infections (UTI), diarrhea, gastroenteritis, wound, etc. The contamination may be as a result of cross-contamination unnoticed or through poor hygienic practice by the food handlers [1], [5], and [6].

\section{Conclusion}

It is now shown that opportunistic pathogens such as $C$. freundii, E. c oli, P. mirabilis and P. vulgaris are present in commercially sold "kunun-zaki" in Chikun Local Government of Kaduna State. Their presence is as a result of faecal contamination of the product, and their presence does not cause disease in healthy human except in immunosuppressed and debilitated people. Since kunun-zaki can serve as vehicle for transmission of pathogens, their presence is not a surprising thing.

\section{References}

[1] Aboh MI, Oladosu P. (2014). Microbiological assessment of Kunun-zaki marketed in Abuja municipal area council (AMAC) in Federal Capital Territory (FCT), Nigeria. Africa Journal of Microbiology. Reserve., 8 (15): 1633-1637.

[2] Adejuyitan JA, Adelakun OE, Olaniyan SA, and Popoola FI. (2008). Evaluating the quality and characteristics of kunu produced from dry-milled sorghum. African Journal of Biotechnology. 7 (13): 2244-2247.

[3] Akoma, O., O. O. Agarry and I. Nkama, (2012). The microbiological quality of freeze-dried Kunun-zaki during production and storage. International Journal of Biology, Pharmacy, and Allied Sciences 1: 1397-1410.

[4] Amusa, N. A. and O. A. Ashaye, (2009). Microbiological and nutritional quality of hawked Kunu (a sorghum based nonalcoholic beverage) widely consumed in Nigeria. Pakistan Journal of Nutrition., 8: 20-25.

[5] Bukar, A., A. Uba and T. I. Oyeyi, (2010). Occurrence of some entropathogenic bacteria in some minimally and fully processed ready-to-eat foods in Kano metropolis, Nigeria. African Journal Food Science, 4: 32-36.

[6] Cheesbrough, M., (2006). District Laboratory Practice in Tropical Countries, Part 2. 1st Edn., Cambridge University Press, Cambridge, ISBN-10: 113944929X, pp: 135-140, 188$189,440$.

[7] Egwim Evans, Amanabo Musa, Yahaya Abubakar and Bello Mainuna (2013). Nigerian Indigenous Fermented Foods: Processes and Prospects DOI: 10.5772/52877.

[8] Elmamood, AM and Doughari, JH, (2007). Microbial Quality assessment of kunun-zaki beverage sold in Girei town of Adamawa State, Nigeria. African Journal of Food Sciences. pp. 11-15.

[9] Gyar S. D, Bala H. and Reuben C. R.(2014). Bacteriological Quality Assessment of Nigerian NonAlcoholic Beverage (Kunun-zaki) Sold in Keffi Metropolis, Nigeria. Greener Journal of Microbiology and Antimicrobials ISSN: 2354-2284 Vol. 2 (2), pp. 021-025.

[10] Kawo AH, Abdulmumin FN. (2009). Microbiological quality of prepackaged sweets sold in metropolitan Kano, Nigeria. Bayero Journal of Pure and Applied Science 2 (1): 154-159.

[11] Lawal, O. A., (2012). Microbial quality of Kunun-zaki beverage sold in Ile-Ife, Osun State. Journal of Food Technology, 10: 4-7.

[12] Maji, A. A., J. Omale and O. E. Chigozie, (2011). Effect of chemical treatment and pasteurization on the shelf life of Kunun zaki (sorghum and maize gruel). European Journal of Food 1: 61-70.

[13] Nyanzi, R. and Jooste, P. J. (2012). Cereal-Based Functional Foods. DOI: 10.5772/50120.

[14] Ogbonna, I. O., Opobiyi, M. Y. Katuka, B., and Waba, J. T, (2011). Microbial evaluation and proximate composition of kunun-zaki an indigenous fermented food drink consumed predominantly in Northern Nigeria. Internet Journal of Food Safety, 13 (2011), pp. 93-97.

[15] Reddy, G, Altaf, M., Naveena, B. J., Venkateshwar, M., and Kumar, E. V, (2008). Amylolytic bacterial acetic acid fermentation- A review. Biotechnology Advances 22-34. 